УДК 78 (09)(477.51)

\section{Цитування:}

Vasiuta O. Chernihiv L. Revutsky musik college: scientific and educational work [Чернігівський музичний коледж ім. Л.М. Ревуцького: наукова та навчально-методична діяльність]. Вісник Національної академії керівних кадрів культури $i$ мистеитв : наук. журнал. № 2. Київ : ІДЕЯ ПРИНТ, 2020. С. 181-184.

Vasiuta O. (2020). Revutsky musik college: scientific and educational work. National Academy of Culture and Arts Management Herald: Science journal, 2, 181184 [in Ukrainian].

\author{
Vasiuta Oleg, \\ Ph.D. in Art Studies, Associate Professor, Associate \\ Professor of the Department of Arts in the National \\ University "Chernihiv Collegium" Named \\ after T.G. Shevchenko \\ ORCID https:// orcid.org/0000-0002-0217-3090 \\ rewuch@gmail.com
}

\title{
CHERNIHIV L. REVUTSKY MUSIK COLLEGE: SCIENTIFIC AND EDUCATIONAL WORK
}

The purpose of the article is to highlight the scientific and educational activities of the Chernihiv Music College formed in the regional system of professional music education in the late XX-early XXI centuries. The methodology involves the use of various scientific methods and is based on the analytical, comparative, and cognitive methods of disclosing the impact of research activities to improve the educational process of the college and characterizes the general process of development of the musical culture of Chernihiv region. The scientific novelty of the work is in an attempt to reveal the unity and interrelation of the academic and educational process, in which special, performing, scientific activities are combined, which contributes to the formation of a modern image of the educational institution. The key moment of the introduction of the innovative musiceducational process was the creation of a new type of educational complex National Music Academy of Ukraine named after P.I. Tchaikovsky Chernihiv Music College named after L.M. Revutsky. Conclusions. The musical educational institution of an innovative direction is oriented toward the European vector of development. It takes into account the involvement of various factors in the and educational process, among which the research activity gave an important place, which contributes to the improvement of educational interdisciplinary communication the realization of further professional orientation of the music institution. Expansion of music pedagogy of arts with separation of scientific and educational-methodical activity introduction of innovative professional technologies promotes an increase of modern content of art education, meets initial requirements of the development of the musical culture of the region, improves various aspects of professional music education, forms musicalaesthetic bases of the creative personality.

Key words: local, scientific activity, teaching practice, performance, music education.

Васюта Олег Павлович, кандидат мистецтвознавства, доцент Національного університету «Чернігівський колегіум» ім. Т. Г. Шевченка

Чернігівський музичний коледж ім. Л.М. Ревуцького: наукова та навчально-методична діяльність

Мета роботи полягає у висвітленні наукової та навчально-методичної діяльності Чернігівського музичного коледжу ім. Л.М. Ревуцького, що склалася в регіональній системі фахової музичної освіти кінця XX - початку XXI століть. Методологія дослідження враховує застосування різних наукових методів і базується на аналітичнопорівняльній та когнітивній методиці розкриття впливу дослідницької діяльності на вдосконалення навчальновиховного процесу коледжу. Наукова новизна полягає у спробі розкрити єдність та нерозривність навчальновиховного процесу, в якому поєднується фахова, виконавська, наукова діяльність, що сприяє формуванню сучасного іміджу навчального закладу. Висновки. Музичний навчальний заклад інноваційного спрямування орієнтується на європейський вектор власного розвитку. Враховує запровадження у навчальний процес різних чинників музичної освіти, серед яких дослідницький напрям посідає важливе місце, що сприяє нарощенню освітньої міжфахової комунікації і реалізації подальшої професійної орієнтації музичного коледжу.

Ключові слова: локальний, наукова діяльність, педагогічна практика, виконавство, музична освіта.

Васюта Олег Павлович, кандидат искусствоведения, доцент Нациионального университета «Черниговский коллегиум» им. Т. .Г. Шевченко

Черниговский музыкальный колледж им. Л.М. Ревуцкого: научная и учебно-методическая деятельность

Цель работы состоит в освещении научной и учебно-методической деятельности Черниговского музыкального колледжа им. Л.М. Ревуцкого, что сложилась в региональной системе профессионального музикального образования конца XX - начала XXI столетий. Методология исследования предполагает использование различных научных

(C) Vasiuta O., 2020 
методов и базируется на аналитико-сравнительной и когнитивной методике раскрытия воздействия исследовательской деятельности на совершенствовании учебно-воспитательного процесса колледжа. Научная новизна работы состоит в попытке раскрытия единства и взаимосвязи учебно-воспитательного процесса, в котором объединяются специальная, исполнительская, научная деятельность, что способствует формированию современного имиджа учебного заведения. Выводы. Музыкальное учебное заведение инновационного направления ориентируется на европейский вектор развития. Учитывает задействование в учебный процесс различных факторов, среди которых исследовательскому направлению отводится важное место, что способствует совершенствованию учебной междисциплинарной коммуникации и реализации дальнейшей профессиональной ориентации музыкального заведения.

Ключевые слова: локальный, научная деятельность, педагогическая практика, исполнительство, музыкальное образование.

The relevance of the research topic. In addition, the indisputable factor in contemporary musicology, in the end, cultural science as a whole - there is also the presence of trends in awareness and scientific and exploratory comprehension of the spiritual culture, a certain specificity of being, which has an important influence on the development of professional music education. In the end, musicology studies show a steady tendency of growing interest in the content of those artistic processes that go beyond the local phenomenon and become a significant part of the general course of spiritual culture of Ukraine, in particular musical performance, composer creativity, musical pedagogy of cultural and educational activity in general.

At least in this way, there has been a steady increase in the musical logic of art studies research, which has a significant impact on the formation of the total volume of the holistic Ukrainian music environment. These scientific perspectives have the prospect of their development and allow the "regional", "local" to see the "general" and to explore their interaction with their particular interdependence. For this purpose, the use of the search method of extrapolation, that is, the dissemination of the findings derived from the observation of a separate phenomenon should be extended to other fields of analysis and synthesis of artistic activity.

Analysis of research and publications. Separate researches by $\mathrm{O}$. Badalov, $\mathrm{O}$. Vasyuta, V. Sukhoversky, and others are devoted to the solution of the problems accumulated in the sphere of professional music education of the region.

At the same time, the scientific and educationalmethodical activity of Chernihiv Music College named after L.M. Revutsky has not found sufficient coverage in the modern scientific literature yet.

The purpose of the article. The introduction of a scientific approach corresponds to actual problems both of Ukrainian art studies and teaching and pedagogical practice in particular. Modern musicpedagogical science is increasingly directing the search vector of its interest in a thorough survey of artistic phenomena of a regional level, where regionalisms acts as a certain phenomenon of knowledge, which allows simultaneously to consider several interdependent issues simultaneously.

Firstly, art criticism of regionalists creates broad cognitive possibilities for expanding our knowledge in the direction of macro-generalizations in terms of cost characteristics of various achievements in the field of musical education. Secondly, the application of a specific-purpose scientific approach contributes to a significant expansion of the angle of their analysis.

To a large extent, this is due to the growth of globalization processes of the world civilization development of mankind, the powerful influence of scientific and technological progress on social communication and the search for alternative forms of glocalized spiritual development associated with the peculiarities of the cultural paradigm of a separate state, region, locus.

Presentation of the main research material. Transformational changes in the artistic space of Chernihiv region at the end of the 20th and the beginning of the 21 st century are under the significant influence of the creative musical and pedagogical activity of well-known in the musical circles of Ukraine - the Chernihiv L.M. Revutsky Music College (director - Honored Worker of Arts of Ukraine, secretary of the National All-Ukrainian Music Union V. M. Sukhovsky).

Over the 114 years of its existence (1904), the college has changed its name some times. Preserving the best traditions of national music education, it has prepared several generations of music carriers of Ukraine for practical activity. Over the past 20 years, it works as the unique musical-teaching complex 'Chernihiv L. Revutsky Music College - P.I. Tchaikovsky National Music Academy of Ukraine'(1998).

The influence of the educational complex on the regional musical staff formation and upbringing is of an exceptional nature. For example, widely known in Ukraine musical communities with artistic status "academic": D. Bortniansky Chamber Choir (artistic director and chief conductor - Ivan Bogdanov), Symphony Orchestra "Philharmony" (artistic director and chief conductor of the Honored Art Worker of 
Ukraine - Mykola Sukach); the Folk Choir (artistic director and chief conductor the Honored Art Worker of Ukraine - Volodymyr Kotsur), the ensemble of songs and dances "Siversky Kleinody" (artistic director and chief conductor of the Honored Worker of Arts of Ukraine - Sergey Vovk) of the Chernihiv Regional Philharmonic Center for Festivals and Concert Programs are "genetically" related to the activity of the creative team of the educational complex.

This list can be continued with the creative activity of professional musical groups in Chernihiv region: the brass band (artistic director and chief conductor of the Honored Art Worker of Ukraine Anatoliy Tkachuk), O. Veresay Bandura Choir (artistic director and chief conductor the Honored Artist of Ukraine - Raisa Borsch), as well as the orchestra of Chernihiv Regional T.G. Shevchenko Academic Theater (artistic director and chief conductor - Oleksiy Roschak). The musical complex based on extensive diversification (diversificato Lat. - change, diversity) of musical and pedagogical practice demonstrates the progressive and open nature of the educational process, constantly expanding cooperation in the field of artistic pedagogy with related educational institutions of Ukraine both near and far abroad.

The evolving pedagogical situation induces also the study of the peculiarities of the development of its components from the point of view of the historical educational process, and, on the other hand, facilitates the exchange of creative experience (nowadays it is important). It allows us to check the strength and prominence of the prevailing national musical education system and solve current problems of musical pedagogy by joint efforts.

The latter state was substantially updated during the time of Ukraine's accession to the pan-European public space. On this path, it is important to avoid the mechanical borrowing of "someone else", which may lead to the loss of its own musical self-identity, which corresponds to the formed in time artistic mentality of the Ukrainian society. In this sense, the consideration of the diversification aspects of musical education in its professional-historical context will allow us to find out the features of the concentration of artistic and professional resources in the conditions prevailing in different historical circumstances of the functioning of musical art.

To study their life stability, professional ability, principle sequence, and heredity is an actual task not only of the regions of musical Ukrainianistics but also of national art studies in general. Understanding the process of the interpenetration of different art spheres with the appearance of new musical specialties on this basis can supplement greatly our conception of the true state of musical pedagogy, and not only in its regional dimension.

The consecutive activity of the pedagogical team mastered modern trends in professional music education in its most significant manifestations: pedagogical, performing, and scientific, which became the basis of the unity of the past and present developments. It outlines ways of the next steps that are potentially informative not only for the Chernihiv region but also for the Ukrainian educational space as a whole. When solving the urgent issues of modern musical-professional education is based on historical experience, which allows to justify the best practices in the field of musical education and contributes to a significant increase in the existing pedagogical potential.

It is worth noting that during this time the professional-musical style of the educational institution was formed. It can be found in various teaching and pedagogical actions. Creative communities of the college: symphony orchestra (conductor - Honored Artist of Ukraine O. Shevchuk), mixed choir (leader - People's Artist of Ukraine M. Honcharenko), the orchestra of folk musical instruments (leader - laureate of AllUkrainian and international competitions V. Falaleev), the ensemble of bandura players "Enchanted Desna" (leader - Honored Artist of Ukraine R. Borsch), brass band (leader - laureate of All-Ukrainian and International competitions I. Kishman), chamber orchestra (leader - Honored Artist of Ukraine A. Danilevsky) the ensemble of folk musical instruments "Harmonica" (leader - Honored Artist of Ukraine V.Kozhan), jazz band (leader M.Girnya), quintet of wooden musical instruments, etc. carry out systematic musical and performing activities. In this context, scientific and methodological work becomes an integrative factor in the implementation of a wide range of educational activities.

The scientific search vector of the musical college is realized in the study of musical and pedagogical practice that has developed during the historical course of education. From the point of view of regional musical historiography, a special place belongs to the collective scientific work, embodied in the collection of scientific works "100 years. Chernihiv L.Revutsky Music College (the compiler is Honored Art Worker of Ukraine V.M.Sukhoversky). The structure of the sections in the collection has a clear scientific research and methodological orientation. Detailed historical events and creative and pedagogical activity from the following college departments are covered: choir and conducting, special piano, concertmaster class, general piano, string-bow, folk, wind and percussion instruments, variety of stage. 
The musical content of the research can be arranged in the following sequence.

For example:

Scientific

1. Vasyuta O.P. Musical culture of the Chernihiv region of XX - the beginning of the XXI century: evolutionary dimension: monograph. [2].

2. 100 years. Chernihiv L.Revutsky Music College: Collection of scientific works.[8].

Popular science.

3. Badalov O. Larisa Rogovets: Yesterday, Today, Tomorrow.[1].

4. Zub P. H. Angelina O. Stryha. [4].

5. Malisov N.A. Our Wind Orchestra. [7].

6.Sukhoversky V.M. Evgeniy Vasyliovych Bohoslovsky. [9].

Educational and methodical.

7. Demidenko M.V. Pedagogical Repertoire for the Violinists Ensemble. [3].

8. Ivanko O.P. Concerts for Piano Pedagogical repertoire of the pianist. [6].

9. Ishchenko V.V. Bandur alphabet.

Methodical manual.[7].

Scientific novelty. Scientific-methodological and search activity of the college gains practical meaning and plays a leading role in the process of transformation of the educational space of the Chernihiv region particularly the transition to an innovative system of artistic education. This approach contributes to the affirmation of the philosophy of education as a pluralistic space of equal opportunity.

In this sense, the concept of the dialogue between science and artistic pedagogical practice is becoming increasingly important and has its logical continuation in the constant interaction of the teacher and student whose effective unity strengthens musical-professional orientation.

Conclusions. Scientific and educational activity of the Chernihiv L.Revutsky Music College contributes to the development of the educational process, understanding the historical ways of distributing professional musical education, distribution of pedagogical techniques, tested by time. The scientific approach harmonizes the directions in the field of pedagogical and musicalperforming work.

These approaches allow the wide use of the experience of both domestic and foreign musical education. That is, to feel equal among equal in the general European system of artistic education. They increase the college's competitive ability by relying on its own musical and educational traditions.

\section{Jimepamypa}

1. Бадалов О. П. Лариса Роговець: вчора, сьогодні, завтра. Чернігів: ВКФ Диво, 2012. 84 с.

2. Васюта О.П. Музична культура Чернігівщини XX - початку XXI століття: еволюційний вимір: монографія. Чернігів: Вид. Десна Поліграф, 2017. 295 c.

3. Демиденко М.В. Педагогічний репертуар для ансамблю скрипалів.Чернігів: ВАТ Рекламний комбінат, 2008. 66 с.

4. Зуб П. Г. Ангеліна Олександрівна Стрига Чернігів: Чернігівська ОУНБ ім. В.Г.Короленка, 2003. $24 \mathrm{c}$.

5. Іванько О.П. Концерти для фортепіано: педагогічний репертуар піаніста. Чернігів: Вид. Чернігівський обереги, 2009. 143 с.

6. Іщенко В.В. Бандурна абетка: метод. посібник. Чернігів: Вид. Десна Поліграф, 2019 . Вип.2.112 с.

7. Малісов Н.А. Оркестр наш духовий. Чернігів: Чернігівська ОУНБ ім. В.Г. Короленка, 2003. 27 с.

8. 100 років. Чернігівське музичне училище імені Л.М.Ревуцького: зб. наук. Праць/ Упорядник В. М. Суховерський. Чернігів: Стар, 2004. 170 с.

9. Суховерський В.М. Свген Васильович Богословський. Чернігів: Чернігівська ОУНБ ім. В. Г. Короленка, 2004. 32 с.

\section{References}

1. Badalov O. P.(2012). Larisa Rogovets: Yesterday, Today, Tomorrow. Chernihiv: VKF DYVO [in Ukrainian].

2. Vasyuta O.P. (2017). Musical Culture of Chernihiv Region of XX - the beginning of the XXI century: Evolutionary Dimension: monograph Chernihiv: Desna Polygraph (in Ukrainian).3. Demidenko M.V. (2008). Pedagogical Repertoire for the Violinists Ensemble. Chernihiv: VAT Reklamny kombinat [in Ukrainian].

4. Zub P. H.(2003). Angelina Alexandrina Strig. Chernihiv: Chernigivska OUNB im V.H. Korolenka [in Ukrainian].

5. Ivanko O.P.(2009). Concerts for the Piano Pedagogical repertoire of the pianist Chernihiv: Chernigivski oberehy [in Ukrainian].

6. Ishchenko V.V. Bandur alphabet. Methodical manual Chernihiv: Desna Polygraph [in Ukrainian]

7. Malisov N.A. (2003). Our Wind Orchestra. Chernihiv: Chernigivska OUNB im V.H. Korolenka [in Ukrainian].

8. 100 years. Chernihiv L.Revutsky Music College (2004). Collection of scientific works /Compiler V. Sukhoversky. Chernihiv: Star [in Ukrainian].

9. Sukhoversky V.M. (2004). Evgeniy Vasylieovych Bohoslovsky. Chernihiv: Chernigivska OUNB im V.H. Korolenka [in Ukrainian].

Стаття надійшла до редакиії 10.04.2020 Прийнято до друку 12.05.2020 